\title{
Medijska prezentacija žena pedesetih godina prošlog veka u Jugoslaviji: retradicionalizacija društva vs. emancipacije na primeru Autonomne pokrajine Vojvodine
}

\author{
SMILJANA MILINKOV
}

Filozofski fakultet, Univerzitet u Novom Sadu

\begin{abstract}
Cilj rada je da dekonstrukcijom tekstualnih i vizuelnih poruka u štampanim medijima pokaže proces transformacije ženskih uloga u Autonomnoj pokrajini Vojvodini, koja je uz Autonomnu Kosovsko-metohijsku oblast bila sastavni deo Srbije, jedne od šest republika koje su činile socijalističku Jugoslaviju. Metod istraživanja je analiza medijskog diskursa, koja kritički preispituje društvo i kulturu u kojoj realni sagovornici razmenjuju poruke, a korpus istraživanja čini vojvođanski dnevni list Slobodna Vojvodina/Dnevnik. Početna hipoteza je da nakon značajnog poboljšanja položaja žena u jugoslovenskom društvu i njihove aktivne uloge u kreiranju društveno-ekonomske sfere u periodu 1945-1950, početkom samoupravljanja pedesetih godina dolazi do retradicionalizacije u smislu smanjenja društveno-političkog angažmana žena i masovnog "povratka" kući i porodici. Repatrijarhalizacija društva kulminira talasom nacionalizma devedesetih godina i raspadom Socijalističke Federativne Republike Jugoslavije.
\end{abstract}

Ključne riječi: Jugoslavija, socijalizam, mediji, žene, emancipacija, retradicionalizacija

Zahvaljujući prvom talasu feminizma, liberalnom feminističkom pokretu s kraja 19. i početkom 20. veka žene osvajaju građanske slobode i prava: kretanja, izražavanja, glasanja, obrazovanja i rada. Žene ulaze u sve više društvenih sfera koje su tradicionalno bile dominatno muške - politiku, univerzitet, državnu upravu, a tokom svetskih ratova dok muškarci ratuju žene rade "muške poslove" u industriji. Žene iz radničkog pokreta su tvrdile da one u kapitalizmu trpe višestruku nepravdu, jer sem rada za najniže plate u lošim uslovima bile su opterećene i kućnim poslovima. Tako je uveden socijalistički feminizam kao alternativa građanskom koji je predviđao značaj sindikalnog organizovanja žena u borbi za ekonomsku nezavisnost (prema Holst 2013: 57-59). Istorija južnoslovenskih žena u dvadesetom veku je, delimično, isto- 
rija njihovih borbi u okvirima rivalskih ideologija: socijalističkog feminizma, liberalnog, socijaldemokratskog, anarho i radikalnog feminizma (prema Ramet 1999: 4-5). Sabrina Ramet navodi da su Tito (predsednik Jugoslavije Josip Broz Tito, prim. aut.) i titoisti odbacili termin "feministkinja" jer su ga poistovećivali sa buržoaskim aktivizmom i stoga je predstavljao antisocijalističko razmišljanje, te da za njih ravnopravnost žena nije mogla imati prioritet iznad ili izvan razvoja samoupravnog socijalizma (Ramet 1999:5). I članice Antifašističkog fronta žena (AFŽ) su se ograđivale od feminizma. Tako je na plenumu u februaru 1946. godine uz konstataciju da su se u rad AFŽ-a uključile i žene iz predratnih organizacija, izražena izvesna bojazan od skretanja u feminizam jer je on "u ranijem kapitalističkom sistemu, ograničavanjem aktivnosti ženskih organizacija uglavnom na humanitarne i prosvetarske delatnosti odvraćao žene od borbe za promenu društvenog sistema, što je jedini ispravan put za ostvarenje ravnopravnosti žena" (Božinović 1996: 156). Mada je zapošljavanje žena, kao osnova za potpunu ravnopravnost, bio jedan od osnovnih ciljeva AFŽ-a, u periodu između 1949. i 1952. dolazi do smanjenja broja zaposlenih, naročito žena, te smanjivanja izdataka za društveni standard a povećavanja ulaganja u vojsku. Ove mere usledile su nakon Rezolucije Informbiroa i napada SSSR-a na jugoslovensko rukovodstvo juna 1948. koji su praćeni ekonomskom blokadom i vojnim pretnjama.

Nismo imali laka vremena. Imali smo 48-mu, kad su nam na granici bili ruski vojnici. Onda je trebalo obezbeđivati vojsku, trebalo je ponovo brinuti o njima, da se odbrani ova zemlja. (Stojaković 2007) ${ }^{1}$

Ekonomsku situaciju Jugoslavije pogoršala je i suša leta 1950. godine. U vezi sa velikim otpuštanjem radnika i radnica i zatvaranjem ustanova za zaštitu dece među komunistima, pa i među ženama, vladalo je mišljenje da je zapošljavanje žena u privredi bilo samo kratka epizoda i da će se žene vratiti kući.

Polazeći od tih teorija, često je u privrednim i političkim krugovima isticano, uglavnom neopravdano, da su žene manje produktivne, da često izostaju, pa su pod tim izgovorima otpuštane s posla ili uopšte nisu zapošljavane. (Božinović 1996: 156-167)

Proces emancipacije žena doživljava regresiju pedesetih godina pošlog veka, svega nekoliko godina nakon Drugog svetskog rata.

Muškarci su se vratili iz rata, žene su se vratile kućama i domovima. Ovo je bilo doba domaćica. U mnogim zemljama broj domaćica nije bio veći nego

${ }^{1}$ Sećanje o 1948. društvene radnice Ide Sabo 2006. zabeležila je Gordana Stojaković u intervjuu “Sećanje o ženama u radničkom pokretu, NOB-u i AFŽ-u Jugoslavije i Vojvodine” (Stojaković 2007). 
prvih 10-15 godina nakon rata. [...] Uloga žene je bila da bude podsticajna supruga, majka i domaćica. Politika i proizvodnja su bili zadaci muškaraca. (Holst 2013: 60)

Prema Einhorn, u državama socijalizma nuklearna porodica se naziva "socijalističkom" dok se i dalje smatra osnovnom ćelijom društva, te izostaje preispitivanje rodne podele rada unutar porodice (Einhorn 1993: 39). I na kapitalističkom Zapadu, u Sjedinjenim Američkim Državama period pedesetih godina poznat je kao baby boom jer je značajno skočila stopa nataliteta zahvaljujući poratnoj pronatalističkoj politici (Zaharijević 2007: 435). To je period kada se Jugoslavija, posle sukoba sa Sovjetskim Savezom sve više okreće Zapadu, a prihvatanje američke kulture (džez, holivudska produkcija, proizvodi masovne potrošnje...) imalo je za cilj da pokaže kako je i koliko je jugoslovenski sistem liberalan i kako i koliko se udaljava od sovjetskog modela. Uticaji u popularnoj kulturi i svakodnevici su tokom hladnog rata bili moćan instrument spoljne politike i Zapada i Istoka, a Jugoslavija je u svojoj specifičnoj poziciji predstavljala idealno polje za tu borbu. U tom periodu, od 1949. sa najvećim dometima u 1953. i u 1955. godini, počinje da stiže i američka ekonomska pomoć (Vučetić 2012: 16, 52).

Početkom pedesetih u Jugoslaviji sa jedne strane rukovodstvo komunističke partije (saopštenje člana Politbiroa CK KPJ Milovana Đilasa) formalno stoji iza teza da su "ženski problemi skoro bez izuzetka problemi čitavog socijalističkog društva" te upozorava na "opasnosti koje ženama prete od kapitalističkih i birokratskih snaga” ali se i zalaže da se rad ženskih organizacija nadalje odvija pod patronatom Socijalističkog saveza radnog naroda (Božinović 1996: 171), što dovodi i do ukidanja AFŽ-a 1953., dok sa druge strane stoji uticaj zapadne popularne kulture i potrošačkog društva kroz "američki koncept usmeravanja slobodnog vremena ljudi ka uživanju, odmoru i konzumiranju” (Vučetić 2012: 351).

Jugoslovenski socijalistički sistem, prema Žarani Papić, nije bio lišen tradicionalno-patrijarhalističkog odnosa, a upravo su masovni mediji najčešće reprodukovali građanske stereotipe o mestu i ulozi žene i tako pothranjivali "ideal zadovoljne sposobne, vredne domaćice i supruge i njenog sveta koji ne izlazi iz vidokruga porodične egzistencije. Takozvana ženska štampa predstavlja utočište tradicionalnih ženskih vrednosti, zanimanja i trivijalnih interesa" (Zaharijević i dr. 2012: 105). Kada je reč o uticaju medija na publiku, prema kulturološkom obrtu medijskih istraživanja, uticaj ne završava se kratkoročnim efektima, već se ispoljava kroz dugoročan i stalno prisutni medijski rad u osmišljavanju realnosti. "Mediji i njihovi sadržaji nisu 'uzrok', niti izazivaju 'efekte' neposredno vidljive u ponašanju pojedinaca”. Oni "rade ideološki - promovišu i preferiraju izvesna značenja sveta, rasprostiru jedna značenja a ne druga i služe nekim društvenim interesima bolje nego drugim" (Milivojević 2009). 
Ideja rada je da dekonstruiše medijsku sliku žene u prvoj polovini pedesetih godina u vojvođanskom dnevnom listu Slobodna Vojvodina, te da se kroz prikaz uloga koje mediji nude i afirmišu, pojasni proces retradicionalizacije jugoslovenskog društva, na primeru pokrajine Vojvodine. Pokrajina je odabrana kao case study jer žene na prostoru Vojvodine već osamdesetih godina 19. veka započinju borbu za redefinisanje sopstvenog položaja, osnivaju prve organizacije i pokreću sopstvene listove. Domaćica, Ženski svet i Žena, su prvi listovi namenjeni ženama na srpskom jeziku iz kojih se može čitati hronologija emancipacije žena na prostoru Vojvodine i Srbije (Stojaković 2012: 171). Budući da u ovoj regiji postoji tradicija borbe za bolji položaj žene u društvu i istorijat feminističkih časopisa, ideja je bila da se analizom novina namenjenih širem čitalačkom auditorijumu, istraži kako se proces retradicionalizacije društva na globalnom nivou, pa i socijalističke Jugoslavije, koji pominju pojedine autorke (Zaharijević 2007; Stojaković 2012; Vilenica 2013; Holst 2013) reflektuje na teritoriji Vojvodine.

Uloge namenjene ženama mogu se posmatrati kroz privatnu (supruga, majka, domaćica) i javnu sferu (profesionalna sfera, politički i društveni aktivizam). Savremene feminističke komunikološkinje u istraživanju medija kao ključnih instrumenata za prenošenje rodnih stereotipa pokušavaju da odgovore na pitanja: ko govori, kome i sa kakvim efektom (Van Zoonen 2004)? Analiziranje štampe u funkciji naučnih zaključivanja jedan je od metoda rekonstrukcije događaja iz prošlosti (Stojaković 2012: 50). Mediji su ogledalo društvene stvarnosti, ali i njeni primarni projektanti koji definišu naše živote, modele ponašanja i vrednosne sisteme. Kroz politiku medijske reprezentacije mogu se rasvetliti paradigmatične predstave o ženama, kao i "simbolički kapital" koji se prenosi patrijarhalnom matricom i inkorporira u njihova delovanja, uloge i tela (Višnjić i Mirosavljević 2008: 249).

\section{CILJ, METOD I KORPUS ISTRAŽIVANJA}

\section{Predmet i cilj istraživanja}

Cilj rada je da se analizom tekstualnih i vizuelnih poruka u štampanim medijima (Slobodna Vojvodina/Dnevnik) pokaže proces transformacije ženskih uloga u pokrajini koja je bila sastavni deo socijalističke Jugoslavije. Polazna pretpostavka je da medijski tekstovi mogu poslužiti kao ilustracija društveno-političkih dešavanja u navedenom periodu, odnosno da mogu da ukažu na momenat repatrijarhalizacije društva, u smislu da se jasno očitava period kada se teme koje se bave položajem žene u društvu i promovisanjem rodne jednakosti zamenjuju medijskim sadržajem koji promoviše tradicionalnu ulogu žene, kao supruge, majke i domaćice. 
Teorijsku osnovu istraživanja čini teorija uspostavljanja dnevnog reda (agenda setting) koja polazi od tvrdnje da mediji definišu koje će se teme u nekom vremenskom periodu smatrati važnim za društvo. Upravo određivanje značenja koje se pojedinim temama pripisuje u medijima utiče na njihovo značenje u javnosti, a posredno i na ponašanje publike u odabiru tema. Iako se ovom teorijom medijima ne pripisuje svojstvo da mogu da utiču šta će se misliti, oni, ipak, određuju o čemu će ljudi razmišljati (prema Drašković 2011: 48).

\section{Metod istraživanja}

Istraživanje je rađeno metodom kritičke analize medijskog diskursa. Analiza diskursa kao interdisciplinarna nauka kritički preispituje društvo i kulturu u kojoj realni sagovornici razmenjuju poruke. Ono što je jedinstveno za ovaj istraživački metod jeste da "analiza jedinica većih od rečenice, u konkretnoj upotrebi u kontekstu i situaciji, bolje objašnjava ljudsku komunikaciju i ponašanje" (Savić 1993: 25). Pojam diskursa podložan je različitim interpretacijama i definiše se različito u zavisnosti od konteksta. Tvrdeći da je diskurs upotreba jezika shvaćena kao deo društvene prakse Ferklaf navodi (Fairclough 1996: 311-313) da se jezička analiza odvija kroz tri komunikativna događaja: tekst, diskursnu praksu i društvenu praksu. Ferklaf postavlja tri područja analize medijskih tekstova sa ciljem razumevanja odnosa između komunikacionog procesa i sociokulturnog okruženja. To su problemi: reprezentacije (načina na koji je svet ili događaj predstavlja), identiteta (na koji način su predstavljeni identiteti učesnika u tekstu) i odnosa (analiza odnosa u komunikacionom lancu medija: mediji - političari, mediji - publika i sl.) (Drašković 2011: 52).

Kritička analiza diskursa kao istraživački metod može da ukaže kako javni diskurs elita može da utiče na mnjenje građana i kakvu ulogu taj uticaj igra u reprodukciji društvenih struktura, stoga su važne za medijsku publiku, jer mogu da upute auditorijum da bude svesniji o mogućnostima dezinformisanja i manipulisanja. Kritičke studije diskursa mogu da dekonstruišu kako se očituje, rodnost u diskursnim strategijama nekog medija, i na osnovu toga daju preporuke za bolju praksu (Valić-Nedeljković 2012: 522).

\section{Korpus istraživanja i društveni kontekst analiziranog medija}

Korpus istraživanja obuhvata izdanja vojvođanskog dnevnog lista Slobodna Vojvodina/Dnevnik, od 1950. do 1955. godine. Početak pedesetih godina odabran je jer je to period gašenja Antifašističkog fronta žena, kada više 
nema ozbiljnih protesta, pitanja niti objašnjenja u AFŽ štampi, a sadržaj ispunjavaju saveti za domaćice i druge teme koje su bile namenjene ženama koje primaju dečije dodatke (Stojaković 2012: 177). Slobodna Vojvodina odabrana je za analizu jer je do 1950. rad organizacija Antifašističkog fronta žena redovno praćen, a urednice i saradnice AFŽ listova u Vojvodini imale su obavezu da obezbede tekstove za Slobodnu Vojvodinu sa ciljem da se kroz pozitivne primere afirmiše doprinos žena izgradnji zemlje (prema Stojaković 2012). Takođe, u navedenom periodu dolazi do promene naziva lista i do "modernizacije", te je ideja bila da se vidi kako se taj proces očitava na medijsku predstavu žene.

Kako je obuhvaćen petogodišnji vremenski period, a s obzirom na to da se rad bavi kvalitativnom analizom, navedeni su samo ilustrativni tekstovi koji su odabrani preliminarnim istraživanjem baziranim na pregledanju izdanja za pet različitih dana u toku nedelje za svaki od dvanaest meseci. Jedinica analize su tekstovi, a analizirani su tekstovi u kojima se pominju žene.

Prvi urednik Slobodne Vojvodine koja u Novom Sadu izlazi od novembra 1942. bio je Svetozar Marković Toza. List "namenjen širokim masama" kako je pisalo u zaglavlju bio je glasilo Pokrajinskog narodnooslobodilačkog odbora Vojvodine (Popov 1982: 20), a zatim Narodnog fronta Vojvodine. Prvi broj Slobodne Vojvodine, štampan u partizanskoj bazi, imao je crveno zaglavlje i dve strane.

Slobodna Vojvodina je bio dnevni list namenjen stanovnicima Vojvodine, muškarcima i ženama, a pratio je političku, društveno-ekonomsku, kulturnu i sportsku vojvođansku i novosadsku svakodnevicu. Prema Popovu, u periodu od početka 1950. do kraja 1952. kada je list promenio ime u Dnevnik, Slobodna Vojvodina je kao i cela zemlja doživljavala teške trenutke. U izveštaju Agitpropa Pokrajinskog komiteta Komunističke partije Srbije (PK KPS) za 1950. godinu nije izrečeno mnogo pohvala o Slobodnoj Vojvodini, a ni samo Uredništvo nije bilo zadovoljno izgledom i sadržinom lista. Zbog skučenog prostora na svega četiri strane, na ukupno 20 stubaca dnevno, od čega je deo bio određen za male oglase i razna obaveštenja, nije bilo mogućnosti da se zbivanja i pojave šire komentarišu. Mada je od strane Agitpropa zamereno da je list ispunjen govorima najviših partijskih rukovodioca, kako prenosi Popov, ipak nije savetovano da se govori sažimaju, stoga nije ostajalo prostora za druge informacije i događaje (Popov 1982: 180-181).

U 1952. godini nastavljeno je unapređivanje i osvežavanje sadržine lista, uvedene su mnoge nove stalne rubrike, način pisanja postao je življi i slobodniji. Slobodna Vojvodina je bila rešena da načini snažan prodor ka osvajanju novih kvaliteta i pridobijanju čitalaca (Popov 1982: 197).

Od 1. januara 1953. list se štampa sa plavim zaglavljem i izlazi pod imenom Dnevnik. 


\section{MEDIJSKA PREZENTACIJA ŽENA U VOJVODINI}

\section{Društveni kontekst}

Nakon Drugog svetskog rata, u periodu od 1945. do 1953. žene u Jugoslaviji izborile su jednaka zakonska prava u svim segmentima života. Zakonska ravnopravnost žena garantovana je Ustavom Federativne narodne republike Jugoslavije (FNRJ) usvojenim 31. januara 1946. godine (Petranović 1981: 394). Savezna skupština FNRJ donosi Osnovni zakon o braku, kojim se ustanovljava građanski brak, ženama i muškarcima se dodeljuju jednaka prava i obaveze (puna poslovna sposobnost, ekonomska nezavisnost, pravo na izbor prezimena i jednaka prava i obaveze prema deci (Zaharijević 2008: 422). Ideološki plan podrške načelu ravnopravnosti koji je pretpostavljao masovniji ulazak žena u privredu i politiku prenošen je putem štampanih medija, ulogu transfera poruka ženama preuzimala je štampa AFŽ-a, a dominantne teme su bile opismenjavanje i kulturno uzdizanje žena. Osnov ženske ravnopravnosti bio je u ekonomskoj samostalnosti žena, do koje se dolazilo obrazovanjem i uključivanjem žena u sve segmente života i rada (Stojaković 2012: 68).

U političkim tekstovima objavljenim u Slobodnoj Vojvodini u periodu 1946-49, ženama i muškarcima se šalju poruke koje se tiču radnog angažovanja žena na različitim poslovima: u fabrikama, na poljima, u zemljoradničkim zadrugama, ali i u narodnooslobodilačkom odboru, gde su žene trebale biti predstavnice vlasti. Ženama su ideološkim i partijskim odlukama namenjene aktivne uloge u kreiranju društveno-ekonomske sfere, ali se podržavao i poseban društveni plan obrazovanja i edukacije žena. Ipak u svim političkim tekstovima i dalje je važna uloga žene kao majke, kao i čitav niz uloga iz ekonomije nege i brige (Marčetić 2013). ${ }^{2}$

U cilju "otvaranja procesa demokratizacije društva", još u toku 1949. godine preduzimane su mere da se poveća uloga radnika u proizvodnji te je podržana ideja o predaji preduzeća na upravljanje radnim kolektivima. 27. juna 1950. godine donosi se Zakon o upravljanju državnim privrednim preduzećima i višim privrednim udruženjima, što označava početak samoupravljanja (Popov 1982: 180), sa ciljem da se "zemlja preda seljacima, a fabrike radnicima" (Petranović 1981: 520). Nastupaju promene u ekonomskom i političkom sistemu, gde lokalni organi vlasti imaju veći značaj, privredna preduzeća moraju da pokažu pozitivan rezultat, a od radnika se traži veće znanje i sposobnost u radu. S druge strane patrijarhalna svest, koja je u prvim godinama posle rata smatrana nazadnom, vremenom je prevladala i učinila da žene na svakom poslu moraju više da se dokazuju. Društvena

${ }^{2}$ Intervju sa Gordanom Stojaković objavljen je na Portalu o rodu, spolu i demokraciji Libela (www. libela.org, 19. 4. 2013. godine). 
briga o deci i majkama postala je skup projekat. Ženama se nudi visok dečji dodatak tako da mnoge napuštaju posao (Stojaković 2013: 47-49). Dešavalo se da su u Vojvodini 1951. i 1952. godine žene masovno vraćale kandidature za izbore na lokalnom i regionalnom nivou, jer se muževi i porodica nisu sa tim slagali (Marčetić 2013). Na opštinskim izborima u Vojvodini 1952. među apstinentima su dominirale žene. U 201 selu u Vojvodini bilo je šest sreskih odbora bez i jedne žene odbornika i devet sreskih odbora sa po jednom ženom članicom (Popov 1986: 211).

Paralelno sa uvođenjem samoupravljanja počinje da se smanjuje društveni i politički angažman žena. 1953. ukida se AFŽ, osniva se Savez ženskih društava. Nekoliko godina kasnije, u programu SKJ iz 1958. ističe se da ravnopravnost žena više nije ni politički ni pravni problem, već je problem "ekonomske nerazvijenosti, primitivizma, religioznih shvatanja i drugih konzervativnih predrasuda koji još dejstvuju na život u porodici". Posledica ovog stava je postepeno ukidanje Saveza ženskih društava (1961) i prenošenje ženskih pitanja na državne organe (Zaharijević 2008: 423). Društvena radnica Ida Sabo sećajući se posleratnih godina kaže da su žene koje su bile zaposlene, koje su bile kvalifikovane, isto tako bile sposobne kao što su bili i muškarci.

To da su žene i njihov rad manje vredan, to je još ostatak iz prošlosti, kad je ženski rad upola plaćan od muškog. I tu se morala voditi borba i vodila se borba i u Partiji i u Skupštini. Ja sam recimo, postala član Predsedništva Jugoslavije, to nije mali položaj. Ali vidite, tamo gde je sredina i pre rata bila razvijenija, recimo u Sloveniji, tamo je daleko više žena bilo i na visokim položajima, pa su se i one morale boriti, dokazivati. Dakle, žena se morala daleko više dokazivati u svom radu, bez obzira, bila za razbojem, bila sudija, bila lekar, bila politički radnik, morala se daleko više dokazivati. Nije lako menjati zaostalu svest. Nije se to moglo preko noći. Bez obzira što je tolko žena učestvovalo u NOB-i, i to puškom u ruci. (Stojaković 2007)

Dakle, socijalistička Jugoslavija je ideološki, zakonski i delimično ekonomski, podržavala emancipaciju žena. Sprovođene su brojne mere u vezi s pravnim izjednačavanjem polova i socijalno-zdravstvenom zaštitom majke i deteta. Ipak, nakon nominalnog izjednačavanja prava muškaraca i žena i početnog entuzijazma, usledio je talas retradicionalizacije. Žene su bile prinuđene da se vrate ulogama u patrijarhalnom domaćinstvu, dok su učesnice u proizvodnji, kroz plaćeni rad trpele dvostruko opterećenje (Vilenica 2013: 16).

\section{Rezultati analize tekstova u Slobodnoj Vojvodini (1950.-1953.)}

Početkom pedesetih godina dnevni list Slobodna Vojvodina izlazi na četiri strane, glavni urednik je Petar Stankov, a tekstovi su nepotpisani. Na osnovu 
sačuvanih redakcijskih izveštaja iz 1950. godine vidi se da su sve rubrike donosile svoje mesečne planove, kao i da su urednici opravdanje za neispunjavanje tih planova videli u malom broju strana, kao i u tome da su pojedine teme bile "pod embargom". A kada su novinari hteli po svaku cenu da ispune plan, događalo se da su napisi bili prazni, "bezidejni" i bez političkog dejstva na čitaoca. Centralni događaj u 1950. godini bilo je donošenje zakona o uvođenju radničkog samoupravljanja. Slobodna Vojvodina je pratila nastajanje i rad radničkih saveta već od početka godine. Kada su prvi saveti izabrani u 22 preduzeća u Vojvodini, već tada je borba za razvoj samoupravljanja trajno ugrađena u program lista (Popov 1981: 181-187).

Pišući o sadržini lista Slobodna Vojvodina za 1950. godinu i nabrajajući bitne događaje i teme kojima se bavio taj pokrajinski dnevni list, Popov u potpunosti izostavlja žene. Analizom Slobodne Vojvodine za potrebe ovog istraživanja može se konstatovati da se žene pominju ${ }^{3}$ samo ukoliko se radi o obeležavanju godišnjica ili praznika i to uglavnom na trećoj a ponekad na drugoj strani, kao što je primer teksta naslovljenog "Žene kulskog sreza predale poklone pionirima za Novu godinu" (8. januar 1950.), ili se izveštava o aktivnostima AFŽ-a.

U tekstu "Već sada pripremiti sezonske vrtiće u seljačkim radnim zadrugama" kao jedan od najvažnijih zadataka za uključivanje žena-majki u poljoprivredu navodi se otvaranje dečijih vrtića i obdaništa. "Jedan od najznačajnijih izvora te radne snage predstavljaju zadrugarke, a naročito žene sa malom decom, koje usled toga do sada nisu učestvovale u radu zadružnih brigada". U tekstu se navodi da su sezonski vrtići otvoreni u svega 74 od ukupno 700 zadruga u Vojvodini, te se konstatuje da je "broj vrtića više nego neznatan u odnosu na broj zadruga". Takođe se piše i o nedostatku vaspitačica i o problemu nedovoljne zainteresovanosti zadrugarki da pohađaju kurseve za pomoćne vaspitačice: "Ovo je u velikoj meri znak nedovoljnog shvatanja značaja stručnog osposobljavanja kadrova u pojedinim zadrugama, kao i nedovoljnog nastojanja mesnih narodnih odbora i frontovskih organizacija u pojedinim mestima da na vreme obezbede predviđeni broj slušalaca". U navedenom tekstu, iako je reč o problemu radnog angažovanja majki, nije data prilika zadrugarkama da iznesu svoje mišljenje.

Budući da se u medijima, pa i u zvaničnoj istoriografiji, retko mogla čuti ženska priča, projektom beleženja sećanja žena različitog društvenog, etničkog, klasnog i profesionalnog statusa, koje je u okviru novosadskih Ženskih studija i istraživanja pokrenula Svenka Savić, data je mogućnost da se sagleda

${ }^{3}$ U radu su analizirani sledeći tekstovi objavljeni u Slobodnoj Vojvodini: "Već sada pripremiti sezonske vrtiće u seljačkim radnim zadrugama" (10. januar 1950.), "Ukupni uspesi AFŽ Vojvodine” (14. januar 1950.), "Organizacije AFŽ Vojvodine takmiče se pred 8. mart” (3. februar 1950.), "Žene pančevačkog sreza najviše pažnje će posvetiti otvaranju porodilišta i otvaranju savetovališta za majke i decu" (9. oktobar 1950.), "Zaštita majke i deteta, prvi i najvažniji zadatak organizacije AFŽ” (10. oktobar 1950.). 
i uticaj društveno-političkih dešavanja na svakodnevicu, privatan život koji, budući da je u patrijarhalnom okviru predodređen ženama, nije bio dovoljno vrednovan kao što je to bila javna - muška sfera. Koliko je bio težak položaj zadrugarki ilustruju sećanja Milice (1931.), koja je u zemljoradničkoj radnoj zadruzi radila dvanaest godina.

Svašta sam radila: kopala, kukuruze brala [...] Onda su nama davali ranu, kad se malo zadruga oformila. Na primer, med, duvan i rakiju su ljudima delili mesto dnevnica. Kad sam se udala, radila sam sve poslove [...] Idem u zadrugu izjutra do četiri sata popodne, a kad se beru kukuruzi - nema radnog vremena. Kad su meni djeca bila mala, ne bi ih i po nedilju dana vidla. Dođem spavaju, odem spavaju. Noću dođeš otud, nema vode, đe smo išli daleko do vode, bilo je pola kilometra i dalje đe bi išli vode donositi. Noću pereš ono što skineš sa sebe, što dječije, a djecu uopšte ne vidiš. (Savić i dr. 2008: 198-199)

I u izveštaju o godišnjem radu AFŽ-a “Ukupni uspesi AFŽ Vojvodine”, kao najvažniji zadatak navodi se pomoć ženi-majci-radnici u vidu otvaranja dečijih restorana i obdaništa. Pažnja je posvećena i "političkom radu sa ženama sa sela" koji "donosi sve bolje rezultate", te se konstatuje da je "u 19 srezova nova pravila o seljačkim radnim zadrugama proučilo 29399 zadrugarki i preko 6 hiljada žena van zadruga", a pominje se i da je pokrajinski odbor AFŽ-a održao dva kursa "za ideološko uzdizanje žena", na mađarskom i rumunskom jeziku (Slobodna Vojvodina, 14. januar 1950.). Ni u ovom tekstu, iako se radi o godišnjem izveštaju krovne ženske organizacije, ne navodi se nijedno žensko ime, niti se citiraju aktivistkinje. Pitanje subjekta, odnosno onog ko u medijima ima priliku da iskaže svoj stav ili mu je dat prioritet, jedan je od bitnih parametara koji ukazuje na značaj koji se pridaje određenim društvenim akterima (Milinkov i Pralica 2013: 49).

Aktivnosti AFŽ-a pominju se i u tekstu "Organizacije AFŽ Vojvodine takmiče se pred 8. mart" koji najavljuje obeležavanje Dana žena:

Žene Vojvodine će i ovog puta da proslave u znaku jače i šire mobilizacije u daljoj izgradnji socijalizma [...] posebno treba tumačiti ulogu žene u novoj Jugoslaviji, isticati likove žena udarnica, zadrugarki, naučnih radnica [...] takođe je potrebno objasniti ženama koliku brigu majkama i deci posvećuje naša socijalistička država. (Slobodna Vojvodina, 3. februar 1950.)

Navedeno može da ilustruje dvostruku objektivizaciju žena, sa jedne strane njima (ženama) treba tumačiti njihovu ulogu (udanice, zadrugarke, naučne radnice) u novoj Jugoslaviji, a potom opet treba njima (majkama) objasniti koliko o njima brine socijalistička država. Može se konstatovati da su žene, iako se na ideološko-praktičnom nivou promoviše njihovo osnaživanje, postavljene u zadati uzročno-posledični okvir: rad i zalaganje za državu - 
izgradnja socijalizma - povratna briga o ženama od strane države, dok se stvarna politička moć nalazi daleko iznad tog okvira. I feministička kritika socijalističkog uređenja polova upravo napada činjenicu da su ženska prava u socijalizmu ostala ograničena na socijalna prava i ženama ne garantuje političke moći (Kobolt 2013: 38).

$\mathrm{U}$ analiziranim primerima samo se u jednom tekstu pominju udarnice i naučne radnice, dok se u ostalima ponavljaju imenice: zadrugarke, radnice, majke, što se može čitati kao deo dominantnog javnog diskursa kada je reč o ženama prvih godina pete decenije 20. veka. "Žena kao majka” bila je centralna ideologija, jer u socijalističkim državama emancipovane žene nisu viđene kao ravnopravne građanke već kao radnice-majke, a ta dualna uloga u svakodnevnom životu bila je i zakonski utemeljena. Figura majke potisnula je svaku ideju o alternativnim ženskim ulogama, kao što bi bila "žena kao građanka" (prema Einhorn 1993: 40).

I u socijalističkoj Jugoslaviji majka-radnica bila je u fokusu državne brige. Razmišljalo se o mogućim modelima društvene solidarnosti sa zaposlenim majkama na nivou podele troškova biološke reprodukcije. Tražilo se njihovo ugrađivanje u poreske sisteme, sistem doprinosa i zdravstvenog osiguranja, kritikovalo se odstupanje od proklamovanih vrednosti, ali do pokretanja šire društvene akcije nikada nije došlo. Što je još značajnije, iako su pojedine komunistkinje, čak i funkcionerke, ukazivale na taj problem, model represivne patrijarhalne porodice i nevidljivog rada u kući nikada nije stavljen u fokus zvanične politike i time doveden u pitanje (Vilenica 2013: 16-17).

Stojaković navodi da je tokom 1951. zapažena pojava opadanja broja zaposlenih žena u svim granama privrede, kao posledica stvaranja novog privrednog sistema. Nakon donošenja uredbe o dodacima za decu iz 1951., majke sa više dece napuštale su posao i posvećivale se odgoju dece, a značajno je uticala i dalje važeća podela poslova na muške i ženske pa su žene pored osmočasovnog rada u privredi morale da obave sve druge poslove (Stojaković 2012: 76).

Navedeno ilustruje i životna priče Milice (1951.) jer njena majka rođenjem ćerke postaje domaćica. "Bio je to rezultat dogovora mojih roditelja jer jaslica i obdaništa na Limanu, gde smo tada stanovali, nije bilo" (Savić i dr. 2008: 458). Slične su i Jasenkine (1946.) uspomene na detinjstvo:

Također me obilježilo nezadovoljstvo mame, mama je bila frustirana kao žena jer je radila samo četiri godine, a bila je profesorica. Ona je završila jugoslavenske jezike i književnost i francuski jezik, a radila je samo četiri godine, jer je to bilo vrijeme kad su se neke žene opredjeljivale da se zaposle, a neke su se dvoumile. Moja mama je u tom dvoumljenju ipak ostala doma. (isto: 379)

Prema sećanju Popova, koji je i sam bio urednik, Slobodna Vojvodina se u 1951. godini suočila sa najvećom finansijskom krizom u svojoj posleratnoj 
istoriji, a bilo je reči i o obustavljanju novina, međutim ipak je i dalje štampana, ali samo na dve strane. Uredništvo je nastojalo da obogati sadržinu novim i privlačnim štivom koristeći se iskustvima drugih tiražnijih listova, pre svega beogradske Politike. Uvode se rubrike kao što su Znate li?, Iz prošlosti, kao i Aktuelni razgovori u kojima se "ćaskalo o svakodnevnim ljudskim brigama, o porodičnim, kućevnim, uličnim i gradskim problemima". Novina su i romani, prvobitno na "visokom književnom nivou", a potom postaju lakog žanra, kao što su detektivski, kaubojski i ljubavni, a i oglasi kao ozbiljan izvor prihoda počeli su da osvajaju prostor (Popov 1981: 194-196). I naredne godine se nastavlja sa unapređivanjem i osvežavanjem lista, a pridobijanje čitalaca išlo je uz pomoć življeg i slobodnijeg načina pisanja, kao i uvođenjem novih rubrika. Nedeljom izlazi i zabavna strana sa "relaksirajućom sadržinom": bili su to saveti domaćicama, ukrštene reči, šahovski problemi. Utorak je bio rezervisan za rubriku posvećenu ženama. Ženski razgovori su pored napisa o podizanju i vaspitanju dece i položaju žena u društvu sadržavali i modne priloge i praktične savete (Popov 1982: 202).

Kada je reč o informativno-političkom sadržaju lista koji Popov navodi za 1951. i 1952. godinu žene se i dalje ne pominju, što bi se moglo protumačiti da su teme kao što je briga o kući, vaspitanju dece, pa i moda, viđene kao deo ženske svakodnevice, te se ne smatraju dovoljno važnim da se izdvoje kao događaji koje je Slobodna Vojvodina ponudila čitaocima. Vladajuće predstave o ženama umnogome zavise od medijskog reprezentovanja, jer medijski tekstovi jesu odraz određene kulture i upućuju na postojanje dominantne politike. "Ženama je dozvoljen pristup tradicionalno ženskim oblastima života, to jest zabavi, kulturi i umetnosti, dok je ostatak rezervisan za muškarce" (Milivojević 2004).

Poslednje izdanje Slobodne Vojvodine štampano je 30. decembra 1952. godine, a od 1. januara 1953. list izlazi pod imenom Dnevnik. Iste godine ukida se AFŽ, a umesto ove organizacije osnovan je Savez ženskih društava.

\section{Rezultati analize tekstova u Dnevniku (1953.-1955.)}

Proces retradicionalizacije položaja žene u jugoslovenskom društvu, koji je započet 1950. godine, a potvrđuju ga medijski tekstovi o ženama u kojima se sve manje govori o ravnopravnom učešću žena u svim segmentima društveno-političkog života, a sve više se potencira njena uloga radnice-majke, dodatno podstaknut komercijalizacijom medijskog prostora usled finansijske krize, nastavlja se i u narednom periodu.

Dnevnik u periodu od 1953. do 1955. godine izlazi na 10 ili 11 strana, a glavni i odgovorni urednik je Petar Stankov. Tekstovi su uglavnom potpisani ili su obeleženi inicijalima. 
Komentar Kovači svoje sreće (1, 2, 3. januar 1954.), objavljen u prazničnom izdanju, potpisuje komunistkinja i predsednica AFŽ Vojvodine zadužena za socijalnu i zdravstvenu zaštitu Ruža Tadić.

Najveći danak našoj zaostalosti plaća baš žena. Ona je ta koja posle osmočasovnog rada u preduzeću ili ustanovi radi još deset, a često i više sati, kod kuće u svom najčešće primitivnom domaćinstvu. [...] Na putu njenoj ravnopravnosti stoje u prvom redu zaostalost i nerazvijenost u oblicima proizvodnje gde stoje nepisani zakoni i norme stvarane hiljadama godina.

Navedeni tekst je gotovo jedini koji se kritički bavi položajem žene u društvu i otvoreno govori o patrijarhatu i problemima uspostavljanja rodne ravnopravnosti.

U tekstu "Fragmenti iz jedne diskusije u Savetu društava organizacije za vaspitanje i staranje dece" objavljenom u Dnevniku 5. januara 1954. potpisanom inicijalima B. M. navodi se: "Većina dece je iz radničkih porodica i kada je majka zaposlena, onda su ta deca na ulici, mi imamo malo dečijih ustanova u kojima bi deca mogla boraviti dok su roditelji na poslu". Na osnovu ovog primera može se čitati tradicionalno postavljanje porodičnih uloga gde se prevashodno od žene očekuje da brine o deci. U tekstu se kritikuje država koja nije obezbedila dovoljno dečijih ustanova, ali se u prvi plan apostrofira da problem boravka dece na ulici nastaje "kada je majka zaposlena".

U životnim sećanjima Pavica (1923.) kao dobre strane socijalizma izdvaja besplatno školovanje i mogućnost vanrednog studiranja jer se uz rad i porodicu moglo završiti dalje školovanje.

Možda i, ne samo proklamovana ravnopravnost žena, koja nam je nažalost, donela duple obaveze, jer su kuća i deca i nadalje - sve do današnjeg dana ostale briga žene i majke [...] Ja sam uvek ostala i žena i majka i ponosim se time. (Savić 2001: 170)

Patrijarhalni obrazac formiranja medijskog diskursa čita se i u rubrici naslovljenoj Žena u domu i društvu, gde se u prvi plan stavlja dom, koji označava privatnu sferu, a potom društvo, koje bi trebalo da predstavi izlazak žene u javnu sferu. U ovoj rubrici pred Dan žena objavljeno je nekoliko tekstova koji takođe mogu da ilustruju da se uz poslove u domaćinstvu i brige za porodicu, ženama prepušta i polje brige i nege u široj zajednici. Vest "Pred osmi mart" (2. mart 1954.), govori o osnivanju društva za brigu i staranje o deci "Nova nada”, a u vesti "U Futogu organizovana tri kursa za žene" (9. mart 1954.), konstatuje se veliki odziv žena koje su učestvovale na tri kursa - jednom domaćinskom (praktično kuvanje) i dva krojačka. Takođe je objavljena i vest 
da su prestali kursevi za prosvećivanje ženske omladine u vojvođanskom mestu Gospođincima, međutim autor/autorka teksta ne navodi razlog.

Za razliku od prvih posleratnih godina kada su u političkim tekstovima povodom 8. marta objavljenim u Slobodnoj Vojvodini ženama i muškarcima slate poruke da su ženama ideološkim i partijskim odlukama namenjene aktivne uloge u kreiranju društveno ekonomske sfere, te da se podržava poseban društveni plan obrazovanja i edukacije žena (Stojaković 2012: 169) u osmomartovskom izdanju Dnevnika iz 1954. godine objavljen je nepotpisan tekst "8. mart", u kojem se umesto aktivističkog stava podstaknutog deklarativnim političkim zalaganjem za načelo ravnopravnosti žene smeštaju u društva za podizanje dece.

Žene Jugoslavije već deseti put proslaviće svoj praznik u potpunoj slobodi [...] ukidanjem dosadašnjeg oblika organizacije žena i njenim pretvaranjem u Savez ženskih društava Jugoslavije, koja deluju zajedno u okviru Socijalističkog saveza radnog naroda, četvrti kongres AFŽ postavio borbu za prosvećivanje i ravnopravnost žena [...] masovno su počela da niču ženska društva za podizanje dece, kursevi za posvećivanje ženske omladine, zimske škole...

Zanimljivo je da je Danu žena posvećen stubac sa leve strane dok središnji deo naslovne strane zauzima tema "Zadruge i krediti".

Za razliku od prethodno analiziranog perioda kada je ovaj dnevni list bio siromašno vizuleno opremljen, u izdanjima od 1953. a pogotovo 1954. može se uočiti promena u vidu brojnijih fotografija i ilustracija, a pojavljuje se i obnaženo žensko telo na fotografijama umetničkih slika. Već pedesetih američki uticaj u jugoslovenskoj modi bio je prisutan zahvaljujući upravo paketima ali i modnim časopisima i kopiranjem uzora iz filmova (Vučetić 2012: 337). Fotografije žena u Dnevniku redovno ilustruju modne strane i modne savete (Žena u svom domu), a sve češće se pojavljuju i fotografije poznatih glumica na filmskim stranama, tako je u Filmskoj hronici koja je izlazila subotom vest o filmu Sabrina (1. decembar 1954.) ilustrovana fotografijom glumice Odri Hepbern koja je igrala glavnu ulogu. Navedeni primer iz novina potvrđuje istorijski podatak da je američki film već pedesetih godina u potpunosti prevladao jugoslovenskim bioskopskim repertoarom, čemu je doprinela promena jugoslovenske spoljnopolitičke orijentacije ali i američki IMG program, kao primamljiva podrška toj promeni (Vučetić 2012: 89).

U rubrikama namenjenim ženama dominatne teme su, sem vaspitanja dece, kako napraviti od starog novo, kućni lekar, mali kurs krojenja - haljina za izlaske, recepti... Jer kao što piše Suzan Douglas još pedesetih godina prošlog veka u potrošačkoj kulturi su žene identifikovane kao odlični potrošači, jer su oglašivači potencirali da se dobra majka i supruga može biti samo ako se uz pomoć određenih proizvoda održava savršen dom (Douglas 1994). 
Tekst "Kako zainteresovati žensku omladinu za širi krug znanja" (Dnevnik, 10. decembar 1954.) takođe ilustruje patrijarhalno viđenje položaja žene u društvu. "I dok su naša preduzeća ove i prošle godine da bi ublažila problem privredne nezaposlenosti, primila veliki broj i to mahom nekvalifikovanih radnica, koje nepotrebno terete platne fondove, dotle se u Vojvodini potpuno gube neki zanati". U izveštaju se konstatuje se da je žena nekvalifikovan ili polukvalifikovan radnik koji tereti državu, te se kritikuju devojke zašto ne odlaze na izučavanje zanata, već ostaju kod kuće i predlaže se širi spektar zanata, a ne samo krojački. Mada izveštaj u naslovu sadrži odrednicu "širi krug znanja" koja bi mogla da uputi na dodatne edukacije u cilju bolje kvalifikacije radnica i na mogućnost višeg obrazovanja devojaka, u samom tekstu devojkama se kao mogući izbor nude samo zanati. Navedena konstatacija da su samo žene nekvalifikovane radnice i da stoga samo one nepotrebno terete platne fondove odraz je mizogenog shvatanja društvenih odnosa.

Takvo simboličko održavanje nejednakosti usporava i otežava stvaranje drugačijeg sveta, sveta jednakosti. Implementacijom definisanih poželjnih rodnih uloga i svakodnevnim ponavljanjem uvreženih predstava o muškosti i ženskosti, mediji socijalizuju za nejednakost. (Višnjić i Mirosavljević 2008: 260)

\section{ZAKLJUČNE NAPOMENE}

Sredinom prošlog veka dolazi do promene u privrednom životu Jugoslavije, menja se društveno-politički kontekst, samim tim i zvaničan diksurs o položaju žene u društvu, što potvrđuje i analiza novinskih tekstova (Slobodna Vojvodina/Dnevnik) objavljenih u Vojvodini. Za razliku od prvih posleratnih godina kada je borba za ženska prava bila ideološki i politički podržavana, a žene imale aktivnu uloge u kreiranju društveno-ekonomske sfere, što je predstavljalo i dominantan medijski diskurs, pedesetih godina, žene se u analiziranim novinama pominju ukoliko se izveštava o aktivnostima AFŽ-a ili obeležavanju godišnjica i praznika. Nakon gašenja AFŽ-a, zaštita majki i dece postaje glavna tema novinskih tekstova o ženama. Takođe, pod uticajem zapadne potrošačke kulture, sve češće se pojavljuju saveti za domaćice, ženski aktivizam zamenjuju modne strane, a pojavljuje se obnaženo žensko telo. Umesto radnica, udarnica, zadrugarka, politički aktivna žena, i građanka, kao poželjne ženske uloge postavljaju se supruga, majka, domaćica, negovateljica i vaspitačica.

Savremene feminističke komunikološkinje u istraživanju medija kao ključnih instrumenata za prenošenje rodnih stereotipa pokušavaju da odgovore na pitanja: ko govori, kome i sa kakvim efektom. Budući da je ovo istraživanje 
pokazalo da se žene najčešće nalaze u ulozi objekata, odnosno da im je retko data prilika da iznesu svoje mišljenje o temama koje se njih tiču, jasno je da je dominatna diskursna strategija analiziranog medija objektivizacija žene.

Analiza pokazuje da odabrani tekstovi u vojvođanskom dnevnom listu Slobodna Vojvodina/Dnevnik mogu poslužiti kao dobra ilustracija društvenopolitičkih dešavanja u navedenom periodu, kao i da ukazuju na repatrijarhalizaciju društva, jer se promenom ponude medijskog sadržaja jasno očitava moment kada se teme koje se bave položajem žene u društvu i promovisanjem rodne jednakosti zamenjuju temama koje promovišu tradicionalno postavljenu ulogu žene, svedenu uglavnom na porodičnu sferu.

Analiza vojvođanskog dnevnog lista može da da još jednu potporu tvrdnjama pojedinih autorki (Zaharijević 2007; Stojaković 2012; Vilenica 2013) da se nakon formalnog izjednačavanja prava žena i muškaraca i emancipacije žena u prvim godinama nakon Drugog svetskog rata, pedesetih godina 20. veka, uvođenjem sistema samoupravljanja i gašenja AFŽ-a započinje proces retradicionalizacije jugoslovenskog društva. Ovaj proces kulminira 90-ih godina kada dolazi do transformacije socijalističkog društva u društvo kojim dominira nacionalni sistem vrednosti, koji dovodi do ratova i masovnog osiromašenja stanovništva, sa dominantnim patrijarhalnim okvirom.

\section{NAVEDENA LITERATURA I IZVORI}

B. M. "Fragmenti iz jedne diskusije u Savetu društava organizacije za vaspitanje i staranje dece”. Dnevnik, 5. januar 1954.

Božinović, Neda. 1996. Žensko pitanje u Srbiji u XIX i XX veku. Beograd: '94 i Žene u crnom.

Douglas, Suzan. 1994. Where the Girls Are. Growing up Female with the Mass Media. New York: Times Books, Random House.

Drašković, Brankica. 2011. "Televizijska slika siromaštva i socijalne inkluzije u Srbiji". Media Discourse of Poverty and Social Exclusion. Dubravka Valić-Nedeljković, ur. Novi Sad: Filozofski fakultet.

Einhorn, Barbara. 1993. Cinderella Goes to Market. Citizenship, Gender, and Women's Movements in East Central Europe. London, New York: Verso.

Holst, Katrine. 2013. Šta je feminizam? Loznica: Karpos.

“Kako zainteresovati žensku omladinu za širi krug znanja”. Dnevnik, 10. decembar 1954.

Kobolt, Katja. 2013. "Nezadovoljna bela žena od dvostrukog do trostrukog opterećenja ili zatočenica dijalektike vica". U Postajanje majkom u doba socijalizma. Beograd, Novi Sad: Uzbuna, Daniel Print.

“Kovači svoje sreće”. Dnevnik, 1, 2, 3. januar 1954.

Milivojević, Snježana. 2009. Javnost i ideološki efekti medija. Dostupno na: http://pescanik. net/javnost-i-ideoloski-efekti-medija (pristup 29. 9. 2014). 
Marcetic, Iva. 2013. "Ekonomija njege i brige izgradila je zemlju”. Dostupno na: http://www. libela.org/razgovor/3654-ekonomija-njege-i-brige-izgradila-je-zemlju (pristup 2. 12. 2013).

Milinkov, Smiljana i Dejan Pralica. 2013. "Slika žene u sportu u medijima u Vojvodini". Izveštavanje o sportu-uvođenje rodne dimenzije. Kikinda: Centar za podršku ženama.

Petranović, Branko. 1981. Istorija Jugoslavije 1918-1978. Beograd: Nolit.

Popov, Dušan. 1982. Istorija Slobodne Vojvodine (1942-1952). Novi Sad: Dnevnik.

Popov, Jelena. 1986. Narodni front u Vojvodini 1944-1953. Novi Sad: Filozofski fakultet.

"Pred osmi mart". Dnevnik, 2. mart 1954.

Ramet P., Sabrina. 1999. Gender Politics in the Western Balkans. Women and Society in Yugoslavia and the Yugoslav Successor States. USA: Penn State University Press.

Savić, Svenka. 1993. Diskurs analiza. Novi Sad: Filozofski fakultet.

Savić, Svenka. 2001. Vojvođanke (1917-1931). Novi Sad: Futura publikacije.

Savić, Svenka, Veronika Mitro i Marijana Čanak. 2008. A što ću ti ja jadna pričat. Novi Sad: Future publikacije.

Slobodna Vojvodina, 14. januar 1950.

Slobodna Vojvodina, 3. februar 1950.

Stojaković, Gordana. 2007. AFŽ Vojvodine 1942-1953 (cd). Novi Sad: izdanje autorke.

Stojaković, Gordana. 2012. Rodna perspektiva u novinama Antifašističkog fronta žena (19451953). Novi Sad: Zavod za ravnopravnost polova.

"U Futogu organizovana tri kursa za žene”. Dnevnik, 9. mart 1954.

Valić Nedeljković, Dubravka. 2012. "Stanje i perspektive istraživanja u oblastima medija. Zašto nema dovoljno medijskih /novinarskih istraživanja?". Kriza i perspektiva znanja i nauke. Nauka i savremeni univerzitet, 1. Niš: Filozofski fakultet.

Van Zoonen, Liesbet. 1994. Feminist Media Studies. London: Sage.

Vasiljević, Lidija i Violeta Anđelković. 2009. Priručnik za medije. Beograd: Ženski INDOK centar.

Vilenica, Ana, ur. 2013. Postajanje majkom u vreme neoliberalnog kapitalizma. Beograd, Novi Sad: Uzbuna, Daniel Print.

Višnjić, Jelena i Mirjana Mirosavljević. 2008. "Problem reprezentacije roda u medijima”. Neko je rekao feminizam. Beograd: Heinrich Böll Stiftung.

Vučetić, Radina. 2012. Koka-kola socijalizam. Beograd: Službeni glasnik.

Zaharijević, Andrijana, ur. 2007. Neko je rekao feminizam? Kako je feminizam uticao na žene XXI veka. Beograd: Žene u crnom, Centar za ženske studije, Rekonstrukcija Ženski fond.

Zaharijević, Andrijana. 2010. Postajanje ženom. Beograd: Rekonstrukcija Ženski fond.

Zaharijević, Andrijana, Zorica Ivanović i Daša Duhaček, ur. 2012. Zorana Papić. Tekstovi 1977-2002. Beograd: Rekonstrukcija Ženski fond, Žene u Crnom, Centar za studije roda i politike Fakulteta političkih nauka.

“8. mart”. Dnevnik, 8. mart 1954. 


\title{
MEDIA PRESENTATION OF WOMEN IN YUGOSLAVIA (FNRY) DURING THE FIFTIES: THE REVIVAL OF TRADITION VS. THE EMANCIPATION OF WOMEN ON THE EXAMPLE OF THE AUTONOMOUS PROVINCE OF VOJVODINA
}

\author{
SUMMARY
}

The aim of this paper is to point to the process of transformation of the women's role in the socialist Yugoslavia through a deconstruction of text and visual messages in the media. We use the method of media discourse analysis, critically examining the society and culture in which real interlocutors exchange messages.The study was performed on the corpus of writings of Slobodna Vojvodina/Dnevnik, a daily newspaper from the province of Vojvodina. The initial hypothesis is that, after a significant improvement in the status of women in the Yugoslav society and their active role in creating the socio-economic sphere from 1945 to 1950, with the beginning of selfgovernment during the fifties there ensues a retraditionalization in terms of reducing the socio-political involvement of women and a mass "return" to the home and family. The patriarchalization of the society culminates before the wave of nationalism during the nineties and during the disintegration of the great Yugoslavia.

Key words: Yugoslavia, socialism, media, women emancipation, retraditionalization 